\title{
14
}

\section{Playing Well With Others: Academic Development as a Team Sport}

\section{Nancy Van Note Chism}

Indiana University-Purdue University Indianapolis

An important first step to attacking significant institutional problems is working across the organizational silos that encompass campus units. This chapter draws upon an experience in collaboration through which an academic development center chose to partner with a variety of campus units to address a vexing problem facing many campuses: unacceptable rates of first-year student retention. The chapter then goes beyond the case to identify the kinds of collaborations that can be created to treat other pressing academic issues and highlight characteristics of successful collaborations that academic development centers can initiate or join.

$\mathrm{O}$ nce upon a time, there was a teaching center that really was not very valued. Requests for consultation were few, workshop attendance was low, and major institutional decisions were always made without the help of the center. Then a change came upon the land, and the center was deluged with requests: Can you do service learning? What about outcome-based assessment? Know anything about "smart classrooms"? The center's teaching consultants went from being able to catch up on reading on a slow Friday afternoon to looking longingly at unread piles of new books and journal articles on their desks, reminiscing about the good old quiet days when there was time to think and read.

This tale describes a general patrern increasingly noted by academic development centers - the change from being a marginalized unit on campus to being the all-purpose teaching and learning support center. While there are 226 
indeed positive aspects to this state of affairs, centers are struggling to define priorities, obtain resources, and respond effectively to a wide range of needs. This chapter describes one strategy for operating in this environment of demand: forming partnerships with other units to address complex institutional needs. It begins with one story, the Gateway Program at Indiana University-Purdue University Indianapolis (IUPUI), and goes on to articulate issues and implications for the work of academic development in general.

\section{The Gateway InItIATIVE}

For years, IUPUI had been concerned with its very low first-year student retention rates. Themes found in faculty experience and the literature (Braxton, Bray, \& Berger, 2000; Cubeta, Travers, \& Sheckley, 2001; Furr \& Elling, 2002; Hu \& St. John, 2001; Johnson, 1997; Lang, 2001; Tharp, 1998) had described the many challenges the institution faced in retaining students: demographic characteristics of the IUPUI student were among the most frequently cited. As an urban institution, IUPUI enrolls a primarily commuter student body. Student employment is high (an average of 19.5 hours per week for full-time freshmen). First-year students also have many family obligations (an average of six hours per week). Together, these obligations are primary to the lives of many students-attention to school ranks a distant third. Over $60 \%$ of IUPUI students lack the core high school coursework needed for college success. Their standardized test scores (an average 957 combined SAT) and high school grade point averages are low. A state-supported institution, IUPUI gets only limited subsidy and is not well financed. Its subsidy and tuition are lower than most other public institutions. Yet, even in periodic comparisons with other urban schools with similar conditions, the first-year student dropout rate has been unacceptably high.

In the face of intense pressure from the trustees and state legislators, the IUPUI administration decided to dramatically step up efforts to improve the retention rate. The dean of University College (UCOL), home of undeclared undergraduates and student academic support services, was asked to collaborate with the director of the Center for Teaching and Learning (CTL) to mount a new initiative. The wisdom of uniting the administrators charged with learning and teaching enhanced the collaborative possibilities of this endeavor from the start.

One of the first steps in the process was to convene a town meeting to hear faculty, students, and administrators define the nature of the problem and suggest solutions. From this initial meeting, a group of key lenders was identified and invited to be part of a ten-person team at a summer academy hosted by 
the American Association for Higher Education. The team was composed of an associate dean for instruction, a department chair, four teaching faculty from the first-year courses, a librarian, a student, and the two convening administrators from University College and the Center for Teaching and Learning. The team termed the first-year courses targeted for their efforts as "Gateway" courses and began to call itself "the Gateway group."

The group proposed several central activities: a regular series of forums at which faculty teaching the courses would share dilemmas and successes; regular meetings with key deans, department chairs, and faculty involved in the Gateway courses to discuss progress and needed resources; a grants program to encourage inquiry, development, and dissemination of promising practices; and enhanced support from University College and the Center for Teaching and Learning for the students and faculty in these courses. The summer team members agreed to serve as a continuing steering group for these activities, but invited several others, including the director of institutional research and the associate dean from the other major school offering Gateway courses, to join the effort.

Throughout the retention initiative, which continues to the present, the collaboration of multiple units on campus has been engaged.

\section{The Office of Information Management and Institutional Research (IMIR)}

This unit was essential for providing good data on the original nature of the problem and emerging patterns of progress. Faculty were extremely attentive to the demographic information. Using numerous charts, the very talented and articulate director of this unit was able to dispel incorrect ideas about the comparative performance of IUPUI with respect to peer institutions and was able to provide facts to support or challenge the suspicions that faculty had about the many ways in which the situations of IUPUI students were like or unlike their own student experiences. The use of data throughout the forums and meetings with schools and departments offering Gateway courses was invaluable. Charts showing rates of withdrawals and grades of " $D$ " or " $F$ " in these courses, coupled with enrollment numbers, were used to identify a core group of troubled Gateway courses for special attention. Sorting the data by sections and departments pointed to the special instructional issues that had to be engaged, enlarging the conception of the attrition problem beyond blaming it on student characteristics and habits. As interventions were attempted or grant projects proposed, IMIR continued to advise on data collection or to supply information useful for planning or tracking progress. 


\section{Administrators in Academic Units}

Issues that were raised at the initial town meeting, such as the teaching reward system within units and the allocation of resources to courses, pointed to administrative decisions that students and faculty identified as detrimental to the Gateway courses. Through the involvement of key administrators in both the guiding of the Gateway initiatives and the examination of courses in their own units, the organizational development dimensions of the issues surfaced. Administrators who had previously invested most of their attention on courses in the major or graduate years were now stimulated to look at the "service" courses as they prepared for the Gateway meetings. The preparation involved dialogue with the faculty who taught these courses and identification of ways in which the dean or chair could better support this work. At the meetings, UCOL and CTL were able to offer services at very critical junctures, increasing the likelihood of use of these services. For example, opportunities to link courses with special critical thinking or tutoring initiatives in $\mathrm{UCOL}$ were articulated and arrangements forged. Issues of curriculum design or orientations to teaching for part-time faculty led to collaborations between CTL and the units. The conversations created the "reachable moment" that the service units needed. At the same time, insights from the schools and departments concerning how the service units might better support them were also articulated, leading to program development.

\section{Research and Sponsored Programs (RSP)}

As the Gateway group sought to mount a grants program, staff from RSP were tapped as consultants to shape the requests for proposals and help run the grants process. RSP staff were also enlisted to help identify external sources of funding for first-year retention activities, as well as to consult with faculty preparing funding proposals to these entities.

\section{Student Life and Diversity (SLD)}

It became apparent that out-of-classroom issues were quite important in the retention puzzle. Creating involvement and a sense of community were identified as key areas for improvement. Members of the SLD administrative team were added to the Gateway group and enlisted as partners in activities as concrete as buying outdoor furniture to encourage student interaction and creating a rich calendar of activities, leadership courses, and diversity study groups. 


\section{Office of Human Resources}

Because many students complained of interactions with staff of administrative personnel, the Office of Human Resources became a partner to the Gateway group in working with staff in such areas as customer service and appreciation for diversity. Having friendly student support services in such areas as financial aid, enrollment, registration, and fee payment emerged as a crucial aspect of retention that needed attention.

Staff from the two major organizing units, UCOL and CTL, also made major contributions to the retention effort, shifting services to areas that needed them most and taking on new projects identified in conversations with academic units or in forums. Administrators from these units pursued institutional arrangements (such as drop-add processes and attendance requirements) that emerged as problematic in the conversations about retention.

These collaborations are resulting in dramatic retention rate increases of more than $3 \%$ each year, as well as in a new sense of community. Faculty teaching first-year courses now know their colleagues in other courses. Administrators know their first-year faculty better. Students and faculty realize that they are facing challenges similar to those of their peers in other units and are trying many different solutions. A rich body of practice-based knowledge is being generated and shared. The Gateway effort was recognized with a Certificate of Excellence in the annual Hesburgh Award competition in 2002, and IUPUI was identified as a model program in the Greater Expectations Program of the Association of American Colleges and Universities.

\section{The Art of Collaboration}

The results of the Gateway initiative are strikingly different from what might have occurred had the IUPUI academic development center approached the issue simply by instituting more workshops on teaching first-year courses or offering consultation services to instructors in these courses. The beauty of collaboration is joint ownership, multifaceted problem definition, and awareness and use of common resources. Occasions for situating the services available from CTL arose from conversations, rather than explicit marketing strategies. Ways to shape the services to meet needs emerged from the forums and meetings and grant proposals. The process of doing the work of academic development became much more organic and nested within the common work of the organization. Finally, the expertise, authority, and resources of other academic or support units were brought to bear on the central issue, an issue so large that it could have totally consumed the CTL, had it been working alone. 
At the same time, some cautions need to be mentioned. Efforts such as Gateway have to be tied to an issue that is central to the work of the institution, an issue that crosses unit boundaries and represents an institutional priority. Second, extra coordination is needed any time multiple units are involved in common work. This appears to slow down the process and make it much more cumbersome. As Brown (1990) points out, "Collaboration may, of course, result in more efficient use of time and money, but few are likely to make that assumption in advance" (p. 246). There is also the possibility of domination and conflict. The loose configuration of the Gateway group (which still resists being called a "committee") was important to the effort described earlier, since it depended on a nonhierarchical, grassroots image. Other cases may call for tighter control, but collaborative groups are likely to grapple with disagreements about decisions and domination of one unit or one voice.

Not every issue that comes to the academic development office requires partnership, but the most important ones do. Questions that involve the central teaching mission of the institution are likely candidates for collaboration. These include such issues such as reforming general education requirements, planning for assessment of student performance or programs, examining an evaluation of teaching system, implementing service learning, using instructional technology wisely, and making the classroom and campus climate more welcoming of diversity. Although members of campus communities are most accustomed to doing their work in parallel play fashion, major efforts such as those described carlier cross unit lines and can best be approached in coordinated fashion.

\section{Formation of a Consortium}

Units with any responsibility for the issue can meet to discuss the nature of the problem or opportunity. They can share information, exchange perspectives, and map out the work that needs to be done. Each unit can agree to take responsibility for accomplishing a piece of the plan. A lead unit or a leadership team of people from two or more units can be designated to coordinate the process, or the units can come together at periodic intervals to review progress. The Gateway program is an example of this, as is the IUPUI Online initiative, which concerns the establishment of a new approach to developing and offering distance education courses. 


\section{Contribution of Talent to Lead Unit}

A lead unit can be designated and other units can contribute staff time to the accomplishment of goals that are important to all. This approach can involve formal release time or special assignment arrangements. When heads of the respective units involved are committed to the project and responsibilities and credit for the work are shared, this strategy makes sense. The CTL at IUPUI has been assigned special staff lines from the campus technology service unit to foster the development of faculty in using the campus online course management system and in learning about effective use of learning technologies. The technology unit understands that these initiatives must be led by those who have learning expertise and a mission to support teaching, rather than those with expertise in infrastructure issues. Both units realize that this collaboration is necessary for their common goals.

\section{Creation of Special Project Team}

Several units can contribute resources to the creation of a new task group or coordinating body formed to approach a project. The new group, which might involve additional staff recruited and hired especially for the project, will usually be situated within one unit, but can also involve joint appointments, special temporary appointments, or consultants. For example, the CTL transferred a staff member to the unit charged with campus assessment to prepare for the visit of the Commission on Higher Education. This person acted in a leadership capacity, involving units throughout campus in contributing information necessary for the self-study.

Whatever format is used, there are several important characteristics of good collaborations that can be described. First, the issue at the heart of the collaboration must be important to all. While it may be more central to the work of one or more units, the problem or opportunity must be thought of as congruent with the mission and values of the unit as well as the institution. In reviewing a variety of successful collaborative efforts, Schroeder (1998) observed that "... most of the collaborative partnerships resulted from a 'triggering' opportunity which represented a particular felt need within the college or community" ( $\$$ 18). It is tremendously helpful if the charge behind the issue comes from central administration, but in cases where this is not so, strong agreement on the importance of the work across units is critical.

Next, those who will be partners in the collaboration should be involved in defining the scope of the issue and the work. While ideas on others who should be involved often arise during the course of the collaboration, it is beneficial at the start of a project for the first collaborators to be intentional in 
identifying the names of others who should be invited to help. As quickly as possible, these units should be engaged in conversations about their interest and possible contributions. Much has been written about the various ways that different units on campus think, particularly the contrast between academic affairs and student affairs units (Brown, 1990; Engstrom \& Tinto, 2000; Fried, 1995; Kuh, 1993; Schroeder, 1998). These differences involve norms, routine ways of acting, status, and values that are deeply entrenched in the positions that various people hold within a campus community. Early involvement of multiple units has the advantage of enabling the problem definition to be expanded.

The work group should also attempt to avoid status distincrions and operate in team fashion. This recognition of mutual interdependence and respect for the expertise of others is essential to the collaboration. Fried (1995) talks about border crossings in the context of student and academic affairs collaborations, but her points are applicable to a broader array of collaborations. She says that actors in border-crossing partnerships:

Don't speak each other's language, aren't familiar with the protocol in each territory and are generally uncomfortable in each other's neighborhoods. Getting to know each other professionally can be considered a cross-cultural experience for each.... When newcomers and established residents develop trusting relationships in which each other makes an effort to understand the worldview of the other, newcomers can be accommodated into the existing structures with a minimum of conflict. (p. 179)

Such respect for multiple points of view is more likely when an additional characteristic, a spirit of inquiry, drives the collaboration. Wenger, McDermotr, and Snyder's (2002) "community of practice" notion describes a promising model for such activities (Chism, Lees, \& Evenbeck, 2002; Wenger, 1999). The collection of information, especially institutional data or findings from the scholarship of teaching and learning or other practice-based inquiry on campus, is particularly helpful in moving collaborations forward. As the members of the group analyze this information and derive implications for practice, they arrive at praxis that enables them to move forward together.

The tendency of work groups is to divide tasks and reassemble when pieces of the work are completed. However, Engstrom and Tinto (2000) point out that "... this type of experience has not typically made individuals aware of the underlying assumptions and values that guide actions" (p. 434). For example, when the task might ordinarily be thought of as a student affairs 
responsibility, engaging a partner from another unit to work with the student affairs partner can create new ideas on approaches to the task as well as new understandings on the part of the partner concerning the complexity and challenge of student affairs work. In the Gateway efforts, UCOL usually identifies the need to support students through tutoring as a way of addressing courses with high failure rates, while CTL tends to look at supporting the faculty member through helping with course redesign or new teaching approaches. Thus, establishing cross-group partnerships for the accomplishment of certain tasks can be very beneficial.

Successful collaborations also involve equitable commitment of resources from the participating units. Although some units are more invested and more resourced than others, each needs to contribute in proportion to its capacity. Inevitably, when one unit takes on substantially more leadership responsibility, it is thought of as dominating the collaboration. The situation can also lead to decline in involvement of other units, who may think that the work of the dominating partner will excuse them from further effort. Balancing contributions takes continued vigilance: It is easy for one unit's enthusiasm or energy to take over.

Sustaining the collaboration involves continued work. Regular communications and the creation of special occasions, such as retreats at a state park or dinners celebrating a milestone, are important support mechanisms. Outside recognition of the importance of the partnership by key leaders at the campus or external groups who make awards or celebrate special projects can do much to maintain the motivation of the individuals who are part of the collaboration. Cultivating group humor through creating insider language or rituals can be enormously helpful as well.

Finally, mechanisms for continued assessment of progress are essential for the maintenance of collaboration. Periodic checks on plan accomplishment, on the impact that the work of the group is having, and on the health of the collaboration itself keep the group focused and committed.

\section{Conclusion}

While not the only solution to the heavy demands made of academic development centers recently, collaboration with campus units is a key strategy. It rightly recognizes that major issues involve many units on campus and can only be addressed well by the formation of partnerships among these groups. Academic development is indeed a team sport. 


\section{REFERENCES}

Braxton, J. M., Bray, N. J., \& Berger, J. B. (2000). Faculty teaching skills and their influence on the college student departure process. Journal of College Student Development, 41, 215-227.

Brown, S. (1990). Strengthening ties to academic affairs. In M. J. Barr, M. L. Upcraft, \& Associates, New futures for student affairs (pp. 239-269). San Francisco, CA: Jossey-Bass.

Chism, N. V. N., Lees, N. D., \& Evenbeck, S. (2002). Faculty development for teaching innovation through communities of practice. Liberal Education, 88(3), $34-41$.

Cubeta, J. F., Travers, N. L., \& Sheckley, B. G. (2001). Predicting the academic success of adults from diverse populations. Journal of College Student Retention, 2, 295-311.

Engstrom, C. M., \& Tinto, V. (2000). Developing partnerships with academic affairs to enhance student learning. In M. J. Barr, M. K. Desler, \& Associates (Eds.), The bandbook of student affairs administration (2nd ed., pp. 425-452). San Francisco, CA: Jossey-Bass.

Fried, J. (1995). Border crossings in higher education: Faculty/student affairs collaboration. In J. Fried \& Associares, Shifting paradigms in student affairs: Culture, context, teaching and learning (pp. 171-188). Washington, DC: American College Personnel Association.

Furr, S. R., \& Elling, T. W. (2002). African-American students in a predominantly White university: Factors associated with retention. College Student Journal, 36, 188-199.

Hu, S., \& St. John, E. P. (2001). Student persistence in a public education system: Understanding racial and ethnic differences. The Journal of Higher Education, 72, 265-286.

Johnson, J. L. (1997). Commuter college students: What factors determine who will persist and who will drop out? College Student Journal, 31, 323-333.

Kuh, G. D. (1993). Cultural perspectives in student affairs work. Lanham, MD: University Press of America.

Lang, M. (2001). Srudent retention in higher education: Some conceptual and programmatic perspectives. Journal of College Student Retention, 3, 217-229.

Schroeder, C. C. (1998). Colluboration and partnerships. Retrieved April 6, 2002, from hetp://www.acpa.nche.edu/seniorscholars/trends/trends $7 . h t m$ 
Tharp, J. (1998). Predicting persistence of urban commuter campus students utilizing student background characteristics from enrollment data. Community College Journal of Research and Practice, 22, 279-294.

Wenger, E. (1999). Communities of practice: Learning, meaning, and identity. Cambridge, England: Cambridge University Press.

Wenger, E., McDermott, R., \& Snyder, W. M. (2002). Cultivating communities of practice: $A$ guide to managing knowledge. Cambridge, MA: Harvard Business School Press.

\section{Contact:}

Nancy Van Note Chism

IUPUI Office of Professional Development

Associate Vice Chancellor for Professional Development

755 W. Michigan St.

Indianapolis, IN 46202

Voice (317) 274-8889

Fax (317) 278-3602

Email nchism@iupui.edu

Nancy Van Note Chism is Associate Vice Chancellor for Professional Development and Associate Dean of the Faculties at Indiana University-Purdue University Indianapolis and Associate Professor of Educational Leadership and Policy Studies at Indiana University. She has worked in academic development since 1985 and has served as president of the Professional and Organizational Development Network in Higher Education. 